\title{
Article \\ Synthesis and Biological Evaluation of Oleanolic Acid Derivatives as Selective Vascular Endothelial Growth Factor Promoter i-Motif Ligands
}

\author{
Huang Zeng ${ }^{1,+}$, Shuangshuang Kang ${ }^{1,+}$, Yu Zhang ${ }^{1}$, Ke Liu ${ }^{1}$, Qian $\mathrm{Yu}^{1}{ }^{1}$, Ding Li ${ }^{1, *}$ and Lin-Kun An ${ }^{1,2, *}$ \\ 1 School of Pharmaceutical Sciences, Sun Yat-sen University, Guangzhou 510006, China; \\ zenghuang8006@163.com (H.Z.); kangshsh@163.com (S.K.); zhangy553@mail2.sysu.edu.cn (Y.Z.); \\ ke.liu.19@ucl.ac.uk (K.L.); yuxi024@163.com (Q.Y.) \\ 2 Guangdong Provincial Key Laboratory of New Drug Design and Evaluation, Guangzhou 510006, China \\ * Correspondence: liding@mail.sysu.edu.cn (D.L.); lssalk@mail.sysu.edu.cn (L.-K.A.); \\ Tel.: +86-20-3994-3058 (D.L.); +86-20-3994-3413 (L.-K.A.) \\ $\dagger$ These authors contributed equally to this work.
}

Citation: Zeng, H.; Kang, S.; Zhang,

Y.; Liu, K.; Yu, Q.; Li, D.; An, L.-K. Synthesis and Biological Evaluation of Oleanolic Acid Derivatives as Selective Vascular Endothelial Growth Factor Promoter i-Motif Ligands. Int. J. Mol. Sci. 2021, 22, 1711. https://doi.org/10.3390/ ijms22041711

Academic Editor: Vojtěch Adam Received: 30 December 2020

Accepted: 4 February 2021

Published: 8 February 202

Publisher's Note: MDPI stays neutral with regard to jurisdictional claims in published maps and institutional affiliations.

Copyright: (c) 2021 by the authors. Licensee MDPI, Basel, Switzerland. This article is an open access article distributed under the terms and conditions of the Creative Commons Attribution (CC BY) license (https:// creativecommons.org/licenses/by/ $4.0 /)$

\begin{abstract}
Vascular endothelial growth factor (VEGF) is an angiogenic growth factor and plays a key role in tumor progression. The C-rich DNA sequence of VEGF promoter can form i-motif structure, which is a potential target for the development of novel anticancer agents. However, there is a limited number of chemotypes as the selective ligands of VEGF promoter i-motif, which leaves much room for development. Herein, we report the discovery of the natural oleanolic acid scaffold as a novel chemotype for the development of selective ligands of VEGF i-motif. A series of oleanolic acid derivatives as VEGF promoter i-motif ligands were synthesized. Subsequent evaluations showed that $3 c$ could selectively bind to and stabilize VEGF promoter i-motif without significant binding to G-quadruplex, duplex DNA, and other oncogene i-motifs. Cell-based assays indicated that $3 c$ could effectively downregulate VEGF gene transcription and expression in MCF-7 cells, inhibit tumor cells proliferation and migration, and induce cancer cells apoptosis. This work provides evidence of VEGF promoter i-motif as an anticancer target and will facilitate future efforts for the discovery of oleanolic acid-based selective ligands of VEGF promoter i-motif.
\end{abstract}

Keywords: vascular endothelial growth factor; oleanolic acid; i-motif; gene transcriptional regulation; antiproliferation; apoptosis

\section{Introduction}

Vascular endothelial growth factor (VEGF) is an angiogenic growth factor, which plays a key role in the process of new blood vessel formation through sprouting or splitting from pre-existing vessels, resulting in stimulation of proliferation, migration, survival, and permeability of endothelial cells [1-3]. VEGF is commonly overexpressed in a variety of cancer cells and associated with tumor progress and viability rate. VEGF receptor and VEGF proteins have been targeted by small molecule inhibitors and monoclonal antibodies for clinically beneficial effect against a variety of tumors [4-6]. However, none of these strategies could affect VEGF overexpression. Therefore, development of strategy for downregulating VEGF overexpression in tumor cells could possibly provide a new approach for anti-cancer therapy.

I-motif structure consists of two parallel duplexes combined in an antiparallel manner via intercalating hemiprotonated cytosine ${ }^{+}$-cytosine base pairs $\left(\mathrm{C}^{+}-\mathrm{C}\right)$. It has been previously suggested that i-motif structure can be formed only under acidic condition in vitro. However, recent studies have shown that i-motif can exist under neutral or physiological $\mathrm{pH}$ under molecular crowding conditions or in the presence of some cations [7,8]. I-motif structure might play important regulatory roles in biological processes, such as DNA replication, gene transcription, and maintenance of genomic stability [9]. Some i-motif 
structures in oncogene promoters have been indicated for regulating gene transcriptions, including PDGFR- $\beta, c-m y c, B C L 2$, and KRAS [10-14]. It has been shown that small molecules IMC-48 and PBP1 (Figure 1) interacted with BCL2 gene promoter i-motif resulting in upregulation of gene transcription [12,15], while B19 and a9 (Figure 1) interacted with c-myc gene promoter i-motif causing downregulation of gene transcription [14,16]. These findings suggested that i-motif structure could be targeted for regulating gene transcription.
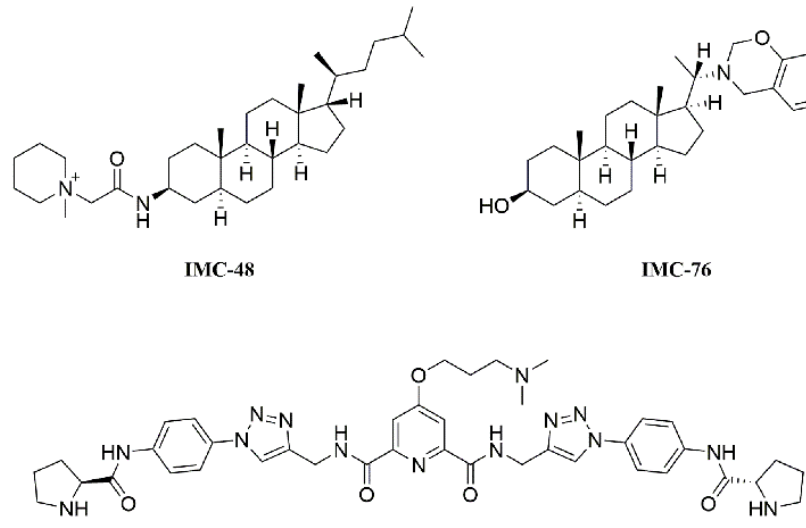

PBP1

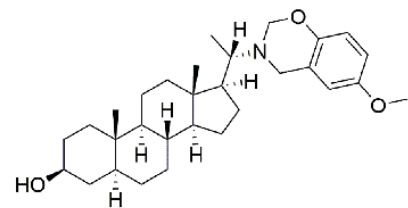

IMC-76
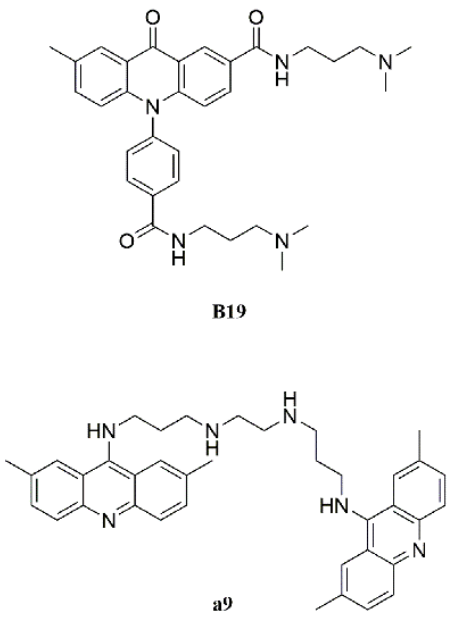

Figure 1. Structures of reported i-motif binding ligands, including steroids IMC-48 and IMC-76, acridone B19, peptidomimetic PBP1, and bisacridine derivatives a9.

The proximal promoter region of VEGF gene has guanine-rich and cytosine-rich strands ( -85 to $-50 \mathrm{bp}$ relative to the initiation of transcription), which contains at least three Sp1 binding sites and controls about 90\% VEGF expression. The polyG/polyC strands on this tract are very dynamic and capable of forming non-B-DNA conformations, characterized as G-quadruplexes and i-motifs, respectively [17]. Several small molecule ligands targeting four-stranded G-quadruplex structures have already been evaluated for their therapeutic potential [18-20]. However, the selective binder to VEGF promoter i-motif has not been developed so far.

It has been shown that steroids IMC-48 and IMC-76 could selectively bind to i-motif structure without significant interaction to G-quadruplex [12]. It is possible that the selectivity of these polycyclic structures was due to their lack of polyaromatic planar chromophore leading to decreased $\pi-\pi$ stacking interaction to G-quartet $[15,21,22]$. However, their binding affinity and stability to i-motif structure is not significant, which requires further improvement [21,23-25]. Natural products and their derivatives are an important source for the discovery of lead compounds in drug discovery and development [26]. In our initial screening from our compound libraries, we found that oleanolic acid derivatives OA-His [27] (Figure S1A) could bind to and stabilize VEGF gene promoter i-motif (Figure S1B-D). However, the binding affinity of OA-His to VEGF promoter i-motif was still not strong enough $\left(K_{\mathrm{D}}=13.3 \mu \mathrm{M}\right)$ and the stabilization effect was not significant enough $\left(\Delta T_{\mathrm{m}}=6.2^{\circ} \mathrm{C}\right)$, which prompted us to synthesize the triterpene oleanolic acid derivatives.

The basic conformational characteristics of i-motif contain cytosine ${ }^{+}$-cytosine base pairs, loops, grooves and phosphate backbone. The lack of four-stranded planar guanine quartets in i-motif is one of the evidential features distinguished from G-quadruplexes. Based on these characteristics, we hypothesized that the ligand without large planar aromatic scaffold could have selective interaction with i-motif structure versus G-quadruplex structure. Herein, we designed and synthesized three types of oleanolic acid derivatives. To evaluate the effect of the side chains at C-28 on the binding affinity to VEGF i-motif structure, Type I compounds were synthesized as shown in Scheme 1 (3a-3q) and Scheme 2 (4a-4o). To evaluate the effect of A-ring on the binding affinity, the opened A-ring Type II compounds with a side chain were also synthesized as shown in Scheme S1 (8a-8h). 
To evaluate the effect of the side chain on A-ring on the binding affinity, type III compounds with various amide side chains at C-2 position were synthesized as shown in Scheme S2 (10a-10d). The synthesized compounds were initially screened by using surface plasmon resonance (SPR) assay. The active compounds with the $K_{\mathrm{D}}$ value less than $50 \mu \mathrm{M}$ were further determined by thiazole orange (TO) displacement assay and circular dichroism (CD) melting assay. The further experiments in vitro and in cells suggested that compound 3c could selectively bind to VEGF promoter i-motif, resulting in downregulation of VEGF gene transcription and proliferation inhibition of tumor cells.

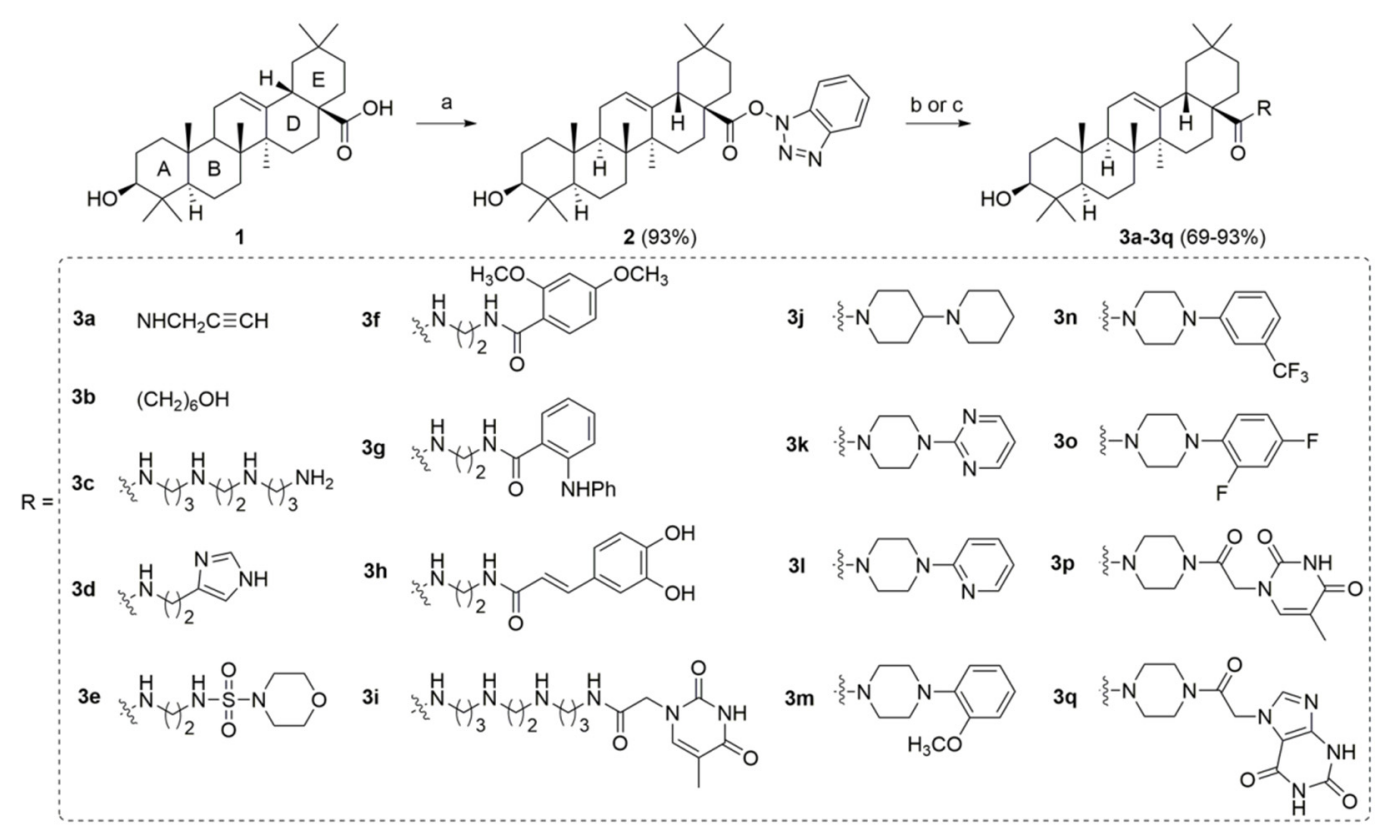

Scheme 1. Synthetic route of type I compounds 3a-3q. Reagents and conditions: (a) HBTU, DIPEA, THF, r.t., 2 h (yield 93\%). (b) Amines, $\mathrm{K}_{2} \mathrm{CO}_{3}$, DMF, r.t., $1 \mathrm{~h}$ (yield 69-93\%). (c) (1) N-Boc-protected amines, $\mathrm{K}_{2} \mathrm{CO}_{3}, \mathrm{DMF}$, r.t., 1 h; (2) $\mathrm{HCl} / \mathrm{EA}$, for $3 \mathrm{c}(80 \%$ yield for two steps).

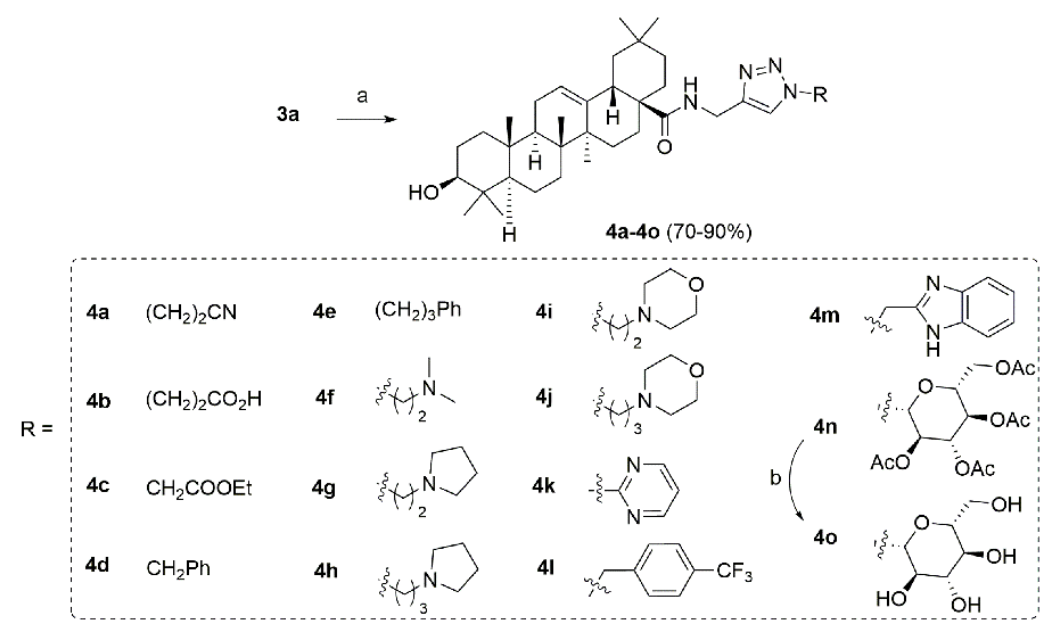

Scheme 2. Synthetic route of type I compounds 4a-4o. Reagents and conditions: (a) $\mathrm{R}-\mathrm{N}_{3}, \mathrm{CuSO}_{4}$, Na-L-ascorbate, $\mathrm{THF} / \mathrm{H}_{2} \mathrm{O}, 40{ }^{\circ} \mathrm{C}, 8 \mathrm{~h}$ (yield 70-90\%). (b) $\mathrm{NaOH}, \mathrm{H}_{2} \mathrm{O}, \mathrm{MeOH}$, r.t., $7 \mathrm{~h}$ (yield 89\%).

\section{Results}

2.1. Chemistry

The type I derivatives were synthesized as shown in Schemes 1 and 2. Compounds $3 a-3 q$ were synthesized via condensation reaction of oleanolic acid (1) with diverse amine 
side chains following previously reported procedure (Scheme 1) [28]. The alkyne 3a could further react with various azide materials through copper (I) catalyzed click chemistry to give the target compounds $4 \mathbf{a}-\mathbf{4} \mathbf{p}$ (Scheme 2) [29].

As shown in Scheme $\mathrm{S} 1$, oleanolic acid reacted with $\mathrm{CH}_{3} \mathrm{I}$ to give the methyl oleanolate 5 , which was oxidized with Jones reagent to give the ketone intermediate 6 [30]. Treatment of compound 6 with m-chloroperoxybenzoic acid produced 3,4-lactone-12,13-epoxy intermediate 7 . The stereochemistry of this epoxy group was determined through a NOE correlation between $\mathrm{H}-12(\delta 3.17)$ and $\mathrm{H}-18(\delta 2.00)$, suggesting an $\alpha$-configuration. The reaction of intermediate 7 with amines mainly gave the type II compounds $8 \mathbf{a}-8 \mathbf{h}$. The NOE spectrum revealed a correlation between the signals of H-13 $(\delta 2.66)$ and $\mathrm{H}-26(\delta 0.96)$, suggesting a $\beta$-configuration for $\mathrm{H}-13$, which have more stable trans junction between rings $C$ and $D[31,32]$.

As shown in Scheme S2, intermediate 6 could be reacted with Stiles' reagent and then treated with DDQ to yield the acid 9 [30]. The type III compounds 10a-10d were prepared via condensation reaction of 9 with amines.

Finally, 44 oleanolic acid derivatives were synthesized and 40 of them were new compounds (3c-3q, 4a-4m, 8a-8h, 10a-10d were newly synthesized; 3a [29], 3b [33], 4n [29], 4o [29] have been previously reported). The structures of the new derivatives were characterized through NMR and HRMS spectra. The purity of all derivatives for biological evaluation was assessed through evaporative light scattering detector (ELSD)/high performance liquid chromatography (HPLC) method and determined to be more than $95 \%$.

\subsection{Initial Screening}

SPR experiments were carried out to investigate the binding affinities of the synthesized compounds to VEGF promoter i-motif, VEGF promoter G-quadruplex and the duplex DNA. The oligomer Py24 and Pu24 were used as the VEGF i-motif and G-quadruplex forming sequence respectively (Table $\mathrm{S} 1$ ). As shown in Table 1, thirteen active compounds were found to have binding affinity to $V E G F$ i-motif with $K_{\mathrm{D}}$ values ranging from 1.95 to $31.3 \mu \mathrm{M}$, and all tested compounds had no obvious binding affinity to VEGF G-quadruplex structure and duplex DNA. The compounds $3 \mathbf{c}, 3 \mathbf{h}$, and $\mathbf{3 i}$ with a long and flexible polyamine chain at C-28 position had good binding affinity to VEGF i-motif with the $K_{\mathrm{D}}$ values of 1.95 (Figure 2A), 3.09 and $5.01 \mu \mathrm{M}$, respectively. In comparison, compounds $\mathbf{3 j - 3 q}$ with relatively rigid side chain did not show binding affinity. In addition, it seems that the hydroxyl terminal functional group of the side chain at C-28 also showed important role on the binding affinity to VEGF i-motif structure. For example, compounds $\mathbf{3 b}$ and $\mathbf{4 o}$ had $K_{\mathrm{D}}$ values of 11.4 and $12.0 \mu \mathrm{M}$, respectively. Besides, most type II compounds with A-ring opened and modified derivatives had no obvious binding affinity to VEGF i-motif. Only two A-ring opened derivatives, $\mathbf{8 b}$ and $\mathbf{8 c}$, showed moderate interaction with $K_{\mathrm{D}}$ values of 31.3 and $21.1 \mu \mathrm{M}$, respectively; 10a-10d did not show obvious interaction to VEGF i-motif.

To confirm their binding affinity, the thirteen active compounds $3 \mathbf{b}-\mathbf{3 e}, \mathbf{3 h}, \mathbf{3 i}, \mathbf{4 a}, \mathbf{4 b}$, $4 \mathrm{k}, 4 \mathrm{~m}, 4 \mathrm{o}, 8 \mathrm{~b}$, and $8 \mathrm{c}$ were selected and further assessed through fluorescent intercalator displacement (FID) assays using thiazole orange. Relative TO displacement ratio (\%) was determined at a fixed Py24 concentration $(1 \mu \mathrm{M})$ with or without the tested compound at a fixed concentration $(5 \mu \mathrm{M})$. As shown in Table 1, the displacement ratios were basically consistent with the $K_{\mathrm{D}}$ values found in SPR assays. Among them, $3 \mathbf{c}$ and $3 \mathbf{i}$ have significant displacement ratios of $67 \%$ and $51 \%$, respectively. 
Table 1. Equilibrium binding constants $\left(K_{\mathrm{D}}\right)$, relative thiazole orange $(\mathrm{TO})$ displacement ratio $(\%)$ and stabilization temperatures $\left(\Delta T_{\mathrm{m}}\right)$ of the synthesized compounds.

\begin{tabular}{|c|c|c|c|c|c|c|c|c|c|c|c|}
\hline \multirow{2}{*}{ Comp. } & \multicolumn{3}{|c|}{$K_{\mathrm{D}}(\mu \mathrm{M})^{1}$} & \multirow{2}{*}{$\begin{array}{c}\text { TO (\%) } \\
2 \\
\text { Py24 }\end{array}$} & \multirow{2}{*}{$\begin{array}{l}\Delta T_{\mathrm{m}} \\
\left({ }^{\circ} \mathrm{C}\right)^{3} \\
\mathrm{Py} 24\end{array}$} & \multirow[t]{2}{*}{ Comp. } & \multicolumn{3}{|c|}{$K_{\mathrm{D}}(\mu \mathrm{M})$} & \multirow{2}{*}{$\begin{array}{c}\text { TO (\%) } \\
\text { Py24 }\end{array}$} & \multirow{2}{*}{$\begin{array}{l}\Delta T_{\mathrm{m}} \\
\left({ }^{\circ} \mathrm{C}\right) \\
\text { Py24 }\end{array}$} \\
\hline & Py24 & $\mathrm{Pu} 24$ & Duplex & & & & Py24 & Pu24 & Duplex & & \\
\hline $\begin{array}{l}\text { OA- } \\
\text { His }\end{array}$ & 13.3 & $>50^{4}$ & $>50$ & n.d. ${ }^{5}$ & 6.2 & $4 g$ & $>50$ & $>50$ & $>50$ & n.d. & n.d. \\
\hline $3 b$ & 11.4 & $>50$ & $>50$ & $27 \%$ & 1.0 & $4 h$ & $>50$ & $>50$ & $>50$ & n.d. & n.d. \\
\hline $3 c$ & 1.95 & $>50$ & $>50$ & $67 \%$ & 19.1 & $4 i$ & $>50$ & $>50$ & $>50$ & n.d. & n.d. \\
\hline $3 d$ & 12.1 & $>50$ & $>50$ & $13 \%$. & -1.6 & $4 j$ & $>50$ & $>50$ & $>50$ & n.d. & n.d. \\
\hline $3 e$ & 13.8 & $>50$ & $>50$ & $20 \%$ & 0.6 & $4 \mathrm{k}$ & 12.3 & $>50$ & $>50$ & $15 \%$ & 3.3 \\
\hline $3 f$ & $>50$ & $>50$ & $>50$ & n.d. & n.d. & 41 & $>50$ & $>50$ & $>50$ & n.d. & n.d. \\
\hline $3 g$ & $>50$ & $>50$ & $>50$ & n.d. & n.d. & $4 m$ & 10.6 & $>50$ & $>50$ & $24 \%$ & 1.8 \\
\hline $3 \mathrm{~h}$ & 3.09 & $>50$ & $>50$ & $37 \%$ & 0.5 & $4 n$ & $>50$ & $>50$ & $>50$ & n.d. & n.d. \\
\hline $3 \mathbf{i}$ & 5.01 & $>50$ & $>50$ & $51 \%$ & 7.0 & 40 & 12.0 & $>50$ & $>50$ & $25 \%$ & 0.1 \\
\hline $3 \mathbf{j}$ & $>50$ & $>50$ & $>50$ & n.d. & n.d. & $8 a$ & $>50$ & $>50$ & $>50$ & n.d. & n.d. \\
\hline $3 k$ & $>50$ & $>50$ & $>50$ & n.d. & n.d. & $8 b$ & 31.3 & $>50$ & $>50$ & $10 \%$ & -0.3 \\
\hline 31 & $>50$ & $>50$ & $>50$ & n.d. & n.d. & $8 c$ & 21.1 & $>50$ & $>50$ & $5 \%$ & 0.2 \\
\hline $3 m$ & $>50$ & $>50$ & $>50$ & n.d. & n.d. & $8 d$ & $>50$ & $>50$ & $>50$ & n.d. & n.d. \\
\hline $3 n$ & $>50$ & $>50$ & $>50$ & n.d. & n.d. & $8 e$ & $>50$ & $>50$ & $>50$ & n.d. & n.d. \\
\hline 30 & $>50$ & $>50$ & $>50$ & n.d. & n.d. & $8 \mathrm{f}$ & $>50$ & $>50$ & $>50$ & n.d. & n.d. \\
\hline $3 p$ & $>50$ & $>50$ & $>50$ & n.d. & n.d. & $8 \mathrm{~g}$ & $>50$ & $>50$ & $>50$ & n.d. & n.d. \\
\hline $3 q$ & $>50$ & $>50$ & $>50$ & n.d. & n.d. & $8 \mathrm{~h}$ & $>50$ & $>50$ & $>50$ & n.d. & n.d. \\
\hline $4 a$ & 19.3 & $>50$ & $>50$ & $19 \%$ & 1.8 & 9 & $>50$ & $>50$ & $>50$ & n.d. & n.d. \\
\hline $4 b$ & 13.0 & $>50$ & $>50$ & $16 \%$ & 1.9 & $10 a$ & $>50$ & $>50$ & $>50$ & n.d. & n.d. \\
\hline $4 c$ & $>50$ & $>50$ & $>50$ & n.d. & n.d. & $10 \mathrm{~b}$ & $>50$ & $>50$ & $>50$ & n.d. & n.d. \\
\hline $4 d$ & $>50$ & $>50$ & $>50$ & n.d. & n.d. & $10 \mathrm{c}$ & $>50$ & $>50$ & $>50$ & n.d. & n.d. \\
\hline $4 e$ & $>50$ & $>50$ & $>50$ & n.d. & n.d. & $10 \mathrm{~d}$ & $>50$ & $>50$ & $>50$ & n.d. & n.d. \\
\hline $4 f$ & $>50$ & $>50$ & $>50$ & n.d. & n.d. & & & & & & \\
\hline
\end{tabular}

${ }^{1} K_{\mathrm{D}}$ values were determined by using surface plasmon resonance (SPR) experiments. ${ }^{2}$ Relative TO displacement ratio (\%) was determined at a fixed i-motif concentration $(1 \mu \mathrm{M})$ either with or without a fixed concentration $(5 \mu \mathrm{M})$ of compounds. ${ }^{3}$ temperature enhancements $\left(\Delta T_{\mathrm{m}}\right)$ were determined using circular dichroism $(\mathrm{CD})$-melting experiments. $\Delta T_{\mathrm{m}}=T_{\mathrm{m}}$ (DNA + ligand) $-T_{\mathrm{m}}$ (DNA). ${ }^{4}$ No significant binding affinity was observed upon the addition of up to $50 \mu \mathrm{M}$ compounds. 5 "n.d." means not determined.

An ideal i-motif ligand should possess two essential features: excellent i-motif binding affinity and excellent i-motif stabilizing ability. In order to investigate the thermodynamic stabilization effect of these thirteen active derivatives on VEGF i-motif, CD melting experiment was also performed. As shown in Figure 2B and Figure S2, with the addition of five equivalents 3c, the melting temperature $\left(T_{\mathrm{m}}\right)$ of Py24 enhanced up to $19.1^{\circ} \mathrm{C}$, indicating that $3 \mathbf{c}$ had significant stabilizing ability to VEGF promoter i-motif. Besides, the compound $3 \mathbf{i}$ had moderate $\Delta T_{\mathrm{m}}$ values $\left(7.0^{\circ} \mathrm{C}\right.$, Table 1$)$. It has been reported that the polyamines could stabilize DNA secondary structures [34,35]. The significantly higher $\Delta T_{\mathrm{m}}$ values of $3 \mathrm{c}$ than the other derivatives promoted us to investigate whether the polyamine side chain (1,5,8,12-tetraazadodecane) of $3 \mathrm{c}$ could stabilize Py24 individually. The results showed that no significant change of $T_{\mathrm{m}}$ value of Py24 was observed with the addition of 1,5,8,12tetraazadodecane (Figure S3), which indicated that the thermal stability effect of $3 \mathrm{c}$ on Py24 was dependent on the properties of overall molecule structure. Further CD melting experiments indicated that $3 \mathbf{c}$ had weak effect on $V E G F$ G-quadruplex and other promoter i-motif structures (BCL2, KRAS, c-kit, PDGFR- $\beta$ ) with $\triangle T_{\mathrm{m}}$ values ranging from 0 to $2.6^{\circ} \mathrm{C}$ (Figure $S 4$ ), indicating $3 \mathrm{c}$ could selectively stabilize VEGF i-motif structure.

Based on these results, compound $3 \mathbf{c}$ was selected for the subsequent biological experiments. 
A

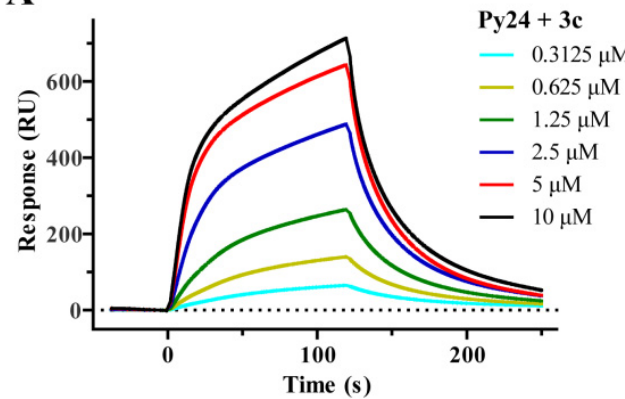

C

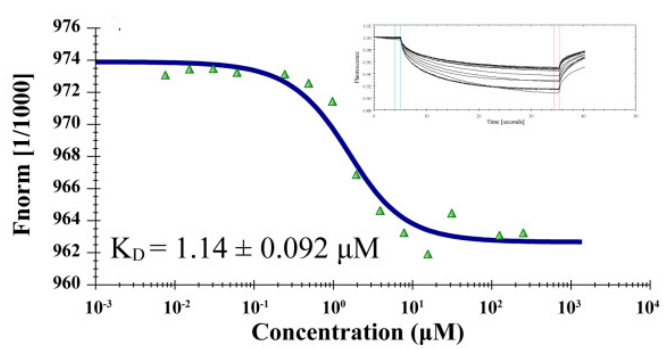

$\mathbf{E}$

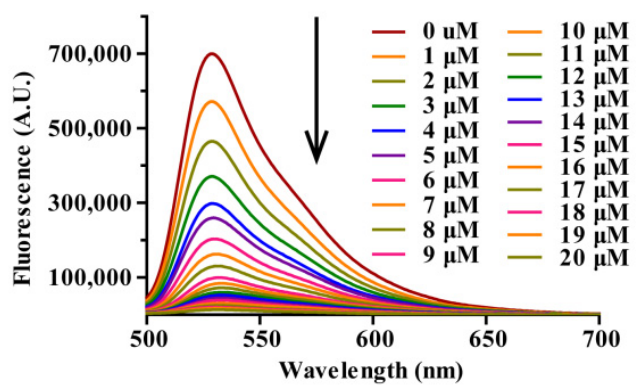

B
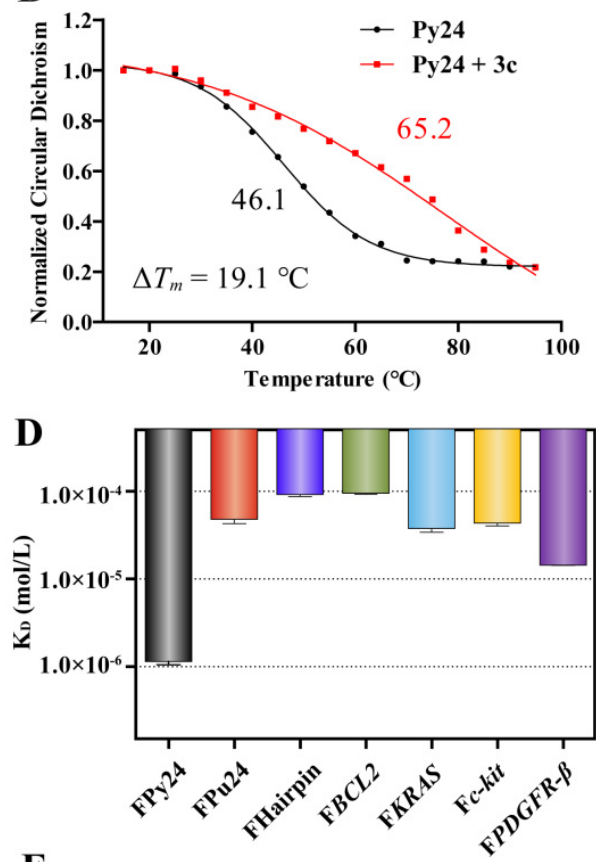

$\mathbf{F}$

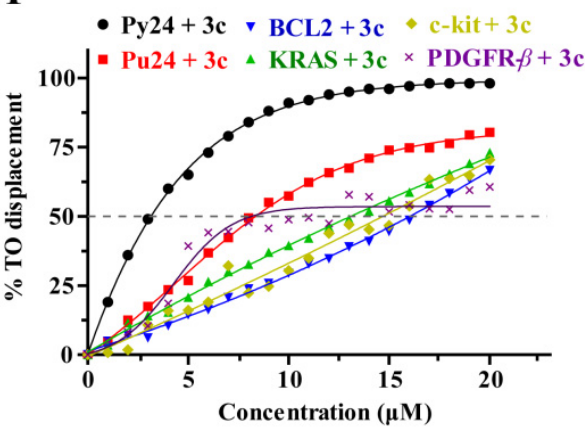

Figure 2. (A) Sensorgrams for the binding of $3 \mathrm{c}$ to VEGF promoter C-rich oligomers (Py24) with $K_{\mathrm{D}}$ value determined to be $1.95 \mu \mathrm{M}$ by using SPR. (B) CD melting curves for Py24 in the absence and presence of 5 equivalents of $3 \mathrm{c}$ in $1 \times$ BPES buffer at $\mathrm{pH}$ 5.5. (C) Microscale thermophoresis (MST) analysis for interactions between 5'-FAM-labeled VEGF promoter C-rich oligomers (FPy24) and 3c. (D) The binding constants $\left(K_{\mathrm{D}}\right)$ were determined by using MST for interaction of 3c with various $5^{\prime}$-FAM-labeled oligomers. (E) Fluorescence spectra analysis of TO displacement experiment for Py24 $(1 \mu \mathrm{M})$ with the increasing addition of $3 \mathbf{c}$. (F) The plots of displacement versus concentration of $3 \mathbf{c}$ for various oligomers $\left(\lambda_{\mathrm{ex}}=480 \mathrm{~nm}\right.$, $\lambda_{\mathrm{em}}=530 \mathrm{~nm}$ ), with $\mathrm{DC}_{50}$ values determined as the concentrations of the ligands required to displace TO by $50 \%$. 3c exhibited DC 50 values of $3.19 \mu \mathrm{M}, 8.08 \mu \mathrm{M}, 8.29 \mu \mathrm{M}, 13.1 \mu \mathrm{M}, 14.7 \mu \mathrm{M}$, and 16.1 $\mu \mathrm{M}$ for Py24, PDGFR- $\beta$, Pu24, KRAS, c-kit, and $B C L 2$.

\subsection{3c Could Selectively Bind to VEGF i-Motif Structure}

To confirm the interaction of $3 \mathrm{c}$ with VEGF i-motif, the microscale thermophoresis (MST) experiment was conducted. After incubation of $3 \mathbf{c}$ with $5^{\prime}$-FAM-labeled VEGF promoter C-rich oligomers (FPy24), MST analysis was performed and $K_{D}$ value was determined to be $1.14 \mu \mathrm{M}$ (Figure 2C), which was consistent with the $K_{\mathrm{D}}$ value of $1.93 \mu \mathrm{M}$ determined by using SPR assay. The interactions of $3 c$ to VEGF G-quadruplex, Duplex DNA and other oncogene promoter i-motif structures, such as BCL2, KRAS, c-kit, PDGFR- $\beta$, were also determined by using MST. As shown in Figure 2D and Figure S5, the interactions of 3c to the G-quadruplex, duplex DNA and other oncogene promoter i-motifs were relatively weaker with the $K_{\mathrm{D}}$ values ranging from 14.4 to $95.1 \mu \mathrm{M}$.

The binding affinity and selectivity of $3 \mathrm{c}$ was further investigated by using TO displacement and the concentrations of $3 \mathrm{c}$ required to displace TO by $50 \%\left(\mathrm{DC}_{50}\right)$ from DNA 
secondary structures were determined. As shown in Figure 2E,F, 3c could effectively displace the bound TO from pre-folded Py 24 with $\mathrm{DC}_{50}$ of $3.19 \mu \mathrm{M}$. In comparison, $3 \mathrm{c}$ exhibited lower affinity for Pu24, BCL2, KRAS, c-kit, and PDGFR- $\beta$ with $D_{50}$ ranging from 8.01 to $16.1 \mu \mathrm{M}$. The results of MST and TO experiments suggested that $3 \mathrm{c}$ had binding selectivity to VEGF promoter i-motif.

The interaction mode was investigated by using ESI-MS experiment. The ESI-MS spectra showed that the peak at $m / z$ 7794.2 corresponding to the mass weight of Py24-3c adduct was observed after annealing VEGF promoter i-motif forming sequence Py24 with $3 \mathrm{c}$ at $\mathrm{pH} 5.0$ (Figure $3 \mathrm{~A}$ ), indicating that $3 \mathrm{c}$ could bind to VEGF promoter i-motif with stoichiometry of 1:1. Conversely, the peak for Py24-3c adduct was not observed under neutral annealing condition (Figure S6). The interaction mode of $3 \mathbf{c}$ with VEGF promoter i-motif was further studied by using isothermal titration calorimetry (ITC) experiment. The negative value of $\Delta H$ indicated that $3 \mathrm{c}$ interacted with $V E G F$ i-motif possibly via van der Waals interaction and hydrogen bond. The negative value of Gibbs free energy $(\Delta G)$ indicated that their binding was a spontaneous process. The binding enthalpy was well fitted with a 1:1 binding mode, and the $K_{\mathrm{D}}$ value was calculated to be $1.13 \mu \mathrm{M}$ (Figure $3 \mathrm{~B}$ ).

A
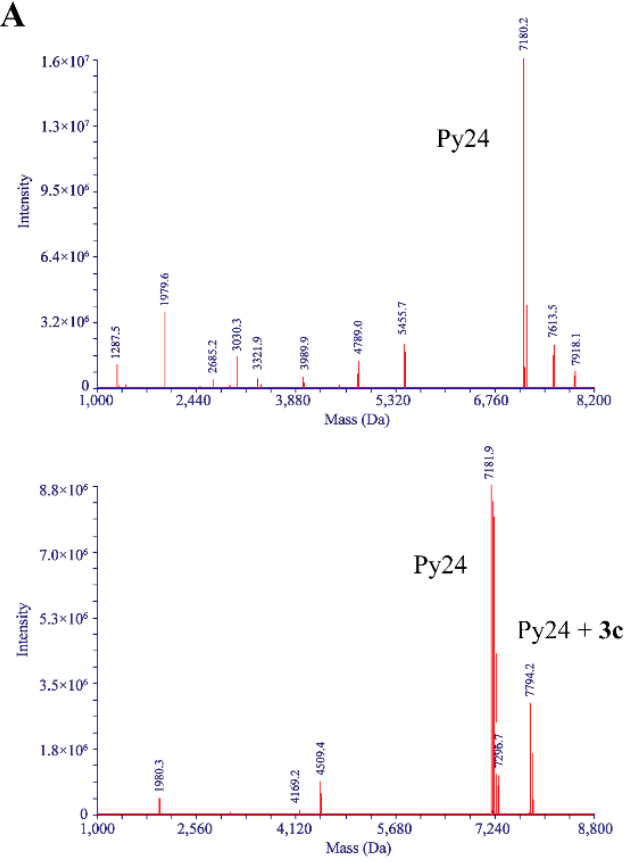

B

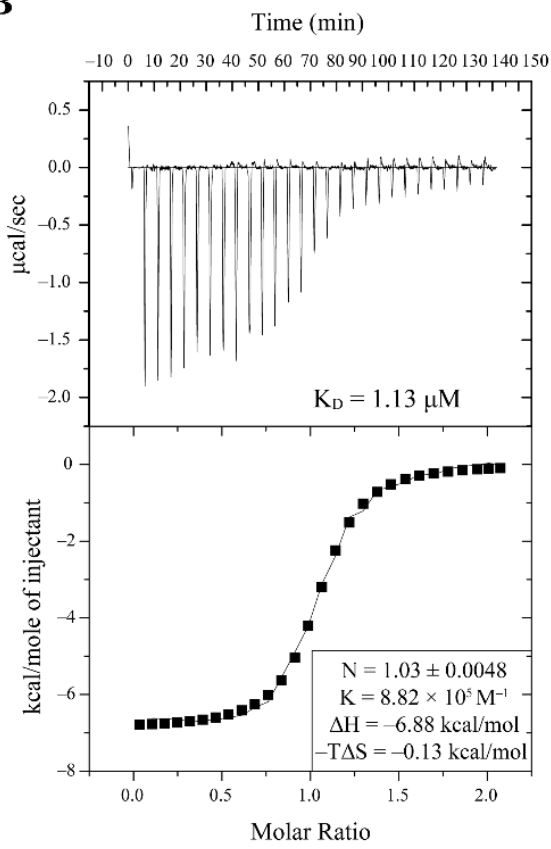

Figure 3. (A) ESI-MS spectra of VEGF promoter C-rich oligomer (Py24) without (upper) and with (bottom) addition of $3 \mathrm{c}$ at $\mathrm{pH}$ 5.0. The mass of $7794.2 \mathrm{Da}$ is corresponding to py24-3c adduct. (B) Isothermal titration calorimetry (ITC) experiment for the binding interaction of Py24 with 3c. The upper panel showed heat change upon ligand titration. The bottom panel showed the integrated data and ITC isotherm (solid line) fitted by a single-site binding model.

\subsection{3c Could Induce the Formation of VEGF i-Motif}

To evaluate the ability of $3 \mathrm{c}$ to induce the formation of VEGF promoter i-motif, CD titration experiment was conducted. The CD spectra of the oligomer Py 24 showed a positive peak at $288 \mathrm{~nm}$ and a negative peak at $265 \mathrm{~nm}$ under acidic condition $(\mathrm{pH} \leq 5.5)$, indicating the formation of i-motif structure (Figure S7). Under the conditions of $\mathrm{pH}>6.0$, the positive peak at $288 \mathrm{~nm}$ decreased significantly, indicating disruption of i-motif structure. Upon the addition of $3 \mathrm{c}$ at $\mathrm{pH}$ 6.0, the $\mathrm{CD}$ spectra exhibited a dose-dependent enhancement of the positive peak $(\sim 288 \mathrm{~nm})$ along with a red shift from $276 \mathrm{~nm}$ to $288 \mathrm{~nm}$, implying that $3 \mathrm{c}$ could induce the formation of VEGF promoter i-motif (Figure $4 \mathrm{~A}$ ). Conversely, $3 \mathbf{c}$ could not induce the formations of $V E G F$ G-quadruplex and other promoter i-motifs, including $B C L 2$, KRAS, c-kit, PDGFR- $\beta$ (Figure S8). 
A

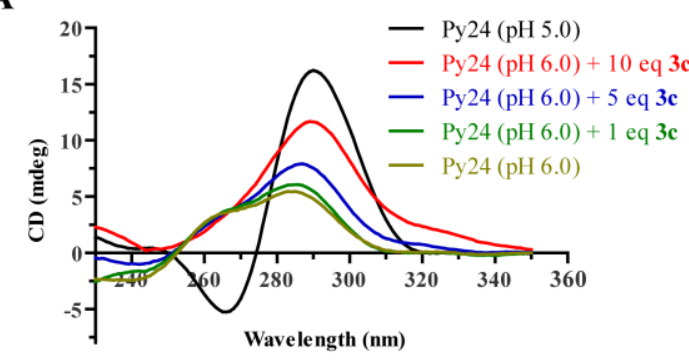

B

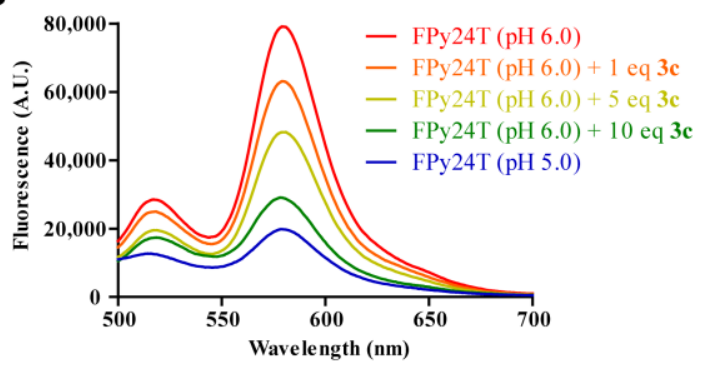

C
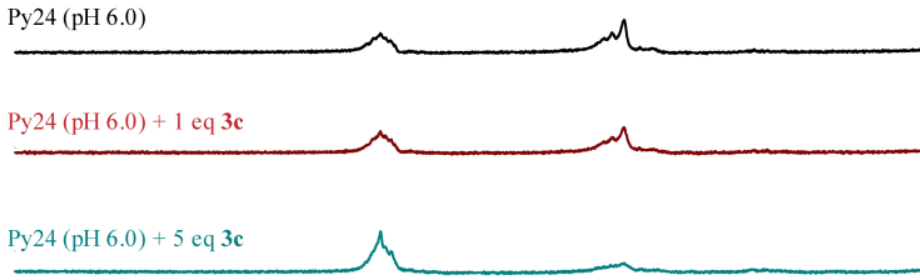

$\mathrm{Py} 24(\mathrm{pH} 6.0)+10$ eq 3c

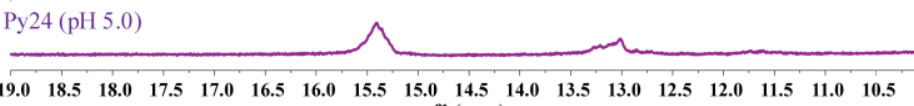

$\begin{array}{llllllllllllllllll}19.0 & 18.5 & 18.0 & 17.5 & 17.0 & 16.5 & 16.0 & 15.5 & 15.0 & 14.5 & 14.0 & 13.5 & 13.0 & 12.5 & 12.0 & 11.5 & 11.0 & 10.5\end{array}$

Figure 4. (A) CD spectra of VEGF promoter C-rich oligomers (Py24) in the absence and presence of $3 \mathbf{c}$ at the indicated $\mathrm{pH}$. (B) Fluorescence resonance energy transfer (FRET) titration experiments of dual labeled VEGF promoter C-rich oligomer (FPy24T) with 3c at pH 6.0. (C) ${ }^{1} \mathrm{H}$ NMR spectra of the imino proton region of Py24 upon titration of $3 \mathrm{c}$ at $\mathrm{pH}$ 6.0.

Fluorescence resonance energy transfer (FRET)-quenching experiment was also conducted to confirm the induction of $3 \mathrm{c}$ to the formation of VEGF i-motif. The VEGF gene promoter i-motif forming sequence containing a FAM (6-carboxy-fluorescein) label at $5^{\prime}$ and a TAMRA (5-carboxytetramethylrhodamine) label at 3' (FPy24T, Table S1) was used. As shown in Figure 4B, the fluorescence quenching of FPy24T solution was obviously found with the titration of $3 \mathbf{c}$, implying that $3 \mathbf{c}$ could induce the formation of VEGF i-motif structure.

${ }^{1} \mathrm{H}$ NMR titration experiment was also performed to study the effect of $3 \mathrm{c}$ on the secondary structure transformation of oligomer Py24. As shown in Figure 4C, at pH 6.0 condition, species corresponding to a duplex/hairpin and an i-motif were both observed in ${ }^{1} \mathrm{H}$ NMR spectra of Py24. The imino protons at $15-16 \mathrm{ppm}$ are characteristic of hemiprotonated $\mathrm{C}^{+}-\mathrm{C}$ base pairs in an i-motif, while the imino peaks at $13 \mathrm{ppm}$ are characteristic of Watson-Crick base pairs in a duplex or hairpin conformation [12]. In comparison, at $\mathrm{pH} 5.0$ condition, signal peaks for i-motif species increased while signal peaks for hairpin/duplex species decreased, implying a shift of the equilibrium from hairpin/duplex to i-motif structure, which was consistent with the CD assay results (Figure S7). Upon addition of 3c, the equilibrium shifts from hairpin/duplex to i-motif structure were observed in a dose-dependent manner (Figure $4 \mathrm{C}$ ). With the addition of 10 equivalents of $3 \mathbf{c}$, no signal ( 13 ppm) for hairpin/duplex species was observed.

The above results strongly supported that $3 \mathrm{c}$ could significantly induce the formation of VEGF promoter i-motif structure.

\subsection{3c Could Downregulate VEGF Gene Transcription and Protein Expression}

To study the effect of $3 \mathbf{c}$ on the gene transcription in cells, dual-luciferase reporter assay was performed. We cloned the wide-type (Wt-VEGF), devoid (Del-VEGF), and mutant (Mut-VEGF) sequences of VEGF corresponding upstream i-motif elements into pGL 4.10 
vector respectively (Figure 5A and Figure S9), and transiently transfected them into MCF-7 cells followed by the treatment with $3 \mathrm{c}$ for $24 \mathrm{~h}$. As shown in Figure 5B, the luciferase activity was found decreased in a dose-dependent manner for the plasmid containing wild-type VEGF promoter i-motif forming sequence. In contrast, no significant decrease of luciferase activity was observed for the plasmid containing devoid and mutated VEGF promoter i-motif forming sequence.

A

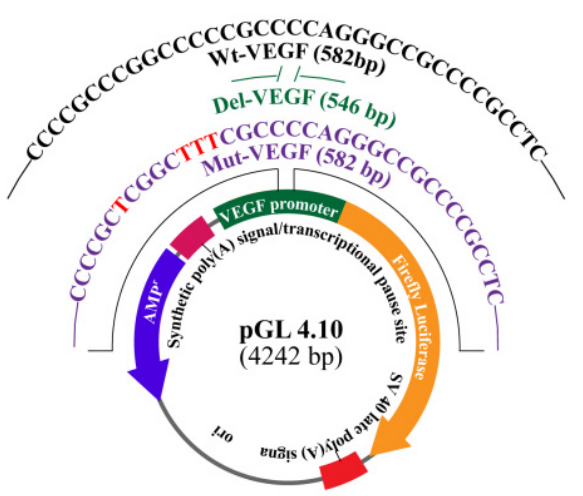

C

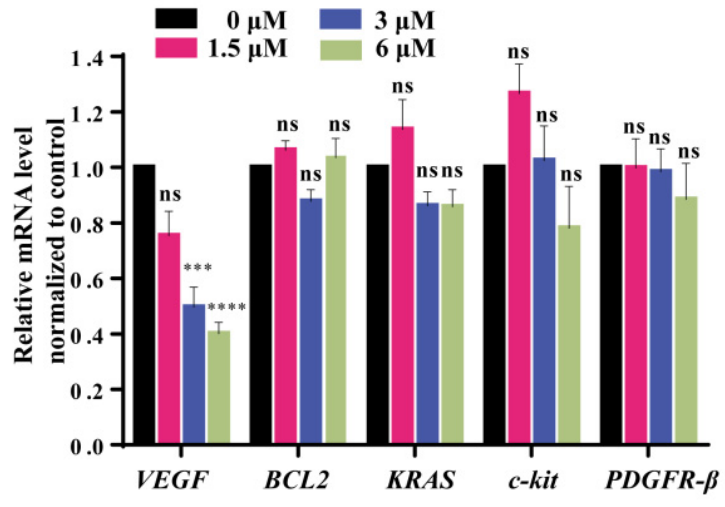

B

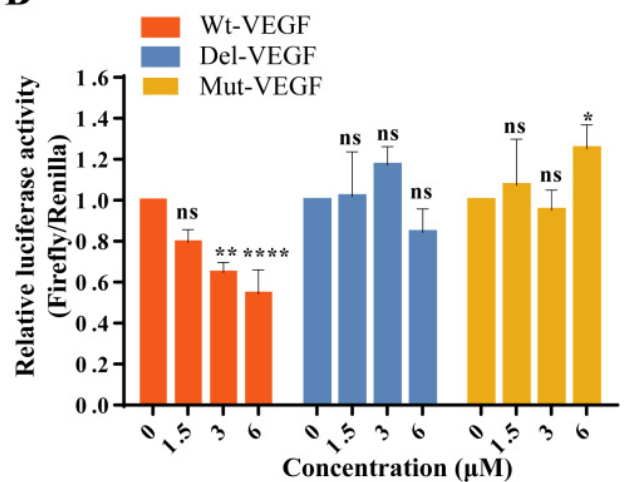

D

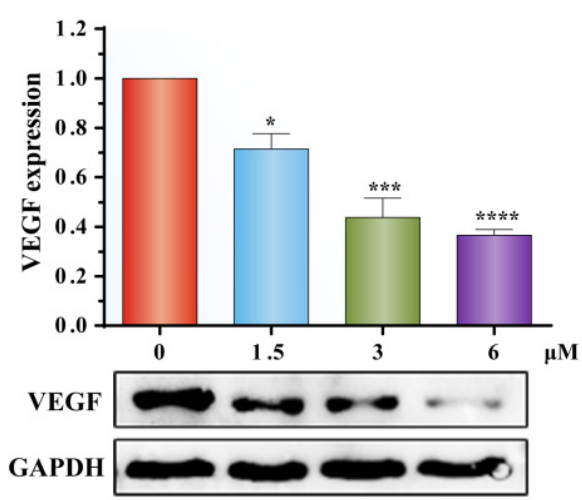

Figure 5. (A) Schematic diagram of dual-luciferase plasmids constructed with Wt-VEGF, Del-VEGF and Mut-VEGF i-motifforming sequences of the VEGF promoter. (B) Effect of $3 \mathbf{c}$ on Wt-VEGF, Del-VEGF, and Mut-VEGF promoter determined by using dual luciferase reporter assays. (C) The mRNA levels of VEGF, BCL2, KRAS, c-kit, PDGFR- $\beta$ in MCF-7 cells were analyzed by using qRT-PCR after incubation with increasing concentration of 3c. (D) Western blot results of VEGF protein in MCF-7 cells in the presence of increasing concentrations of $3 \mathrm{c}$ from 0 to $6 \mu \mathrm{M}$. The GAPDH protein was used as a control. The experiments were repeated for three times. The data are expressed as the mean \pm SEM: $\left(^{*}\right) p<0.05,(* *) p<0.01$, ${ }^{(* * *)} p<0.001,(* * *) p<0.0001$.

Quantitative real time PCR assay was also conducted to analyze the transcription levels. As shown in Figure 5C, after treatment of MCF-7 cells with 3c for 48 h, VEGF mRNA level was found to be reduced significantly in a dose-dependent manner. In contrast, $3 c$ had no significant effect on the transcription of other oncogenes, including BCL2, KRAS, $c-k i t$, and PDGFR- $\beta$.

The effect of 3c on VEGF protein expression was determined by using Western blot experiment. As shown in Figure 5D, 3c could reduce VEGF protein expression in a dosedependent manner in MCF-7 cells. In contrast, $\mathbf{3 c}$ had no significant effect on expression of other oncogene proteins, including PDGFR- $\beta, c-k i t$, and BCL-2 (Figure S10).

These results indicated that $3 c$ could selectively interact with VEGF promoter i-motif, resulting in downregulation of VEGF gene transcription and protein expression in cancer cells. 


\subsection{3c Could Induce Apoptosis and Inhibit Proliferation and Metastasis of Cancer Cells}

Annexin-fluorescein isothiocyante (FITC)/propidine iodide (PI) double-staining flow cytometry was carried out to analyze cell apoptosis induced by $\mathbf{3 c}$ (Figure 6A). After being treated with 3c, the percentages of both early and late apoptotic MCF-7 cells significantly increased. Total $39.6 \%$ of apoptotic cells were found after being treated with $6 \mu \mathrm{M}$ of $3 \mathrm{c}$.

A

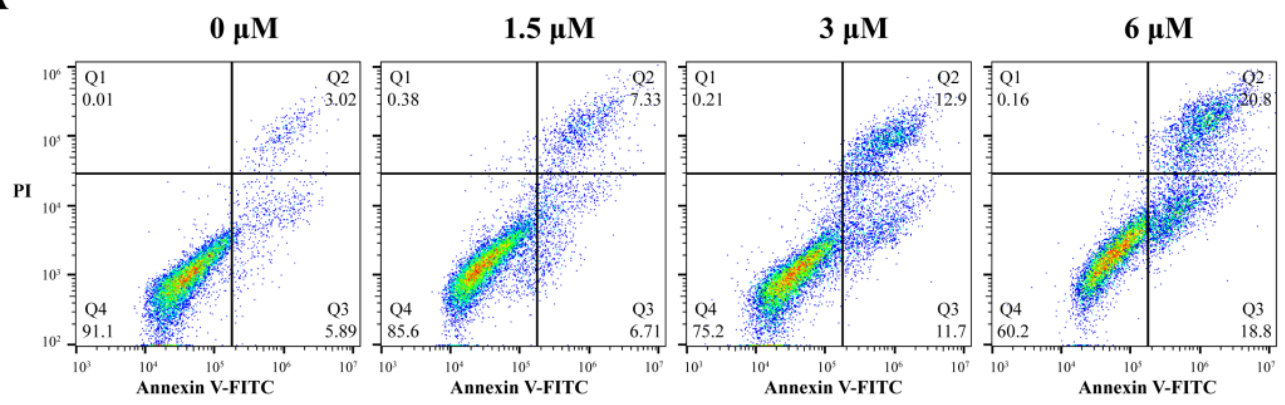

B

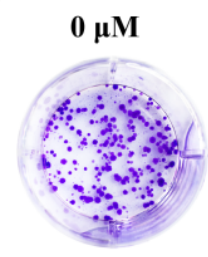

$\mathbf{3} \boldsymbol{\mu M}$

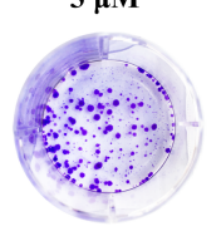

$1.5 \mu \mathrm{M}$

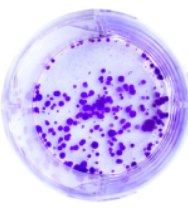

$6 \mu \mathrm{M}$

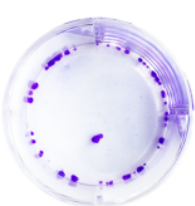

C
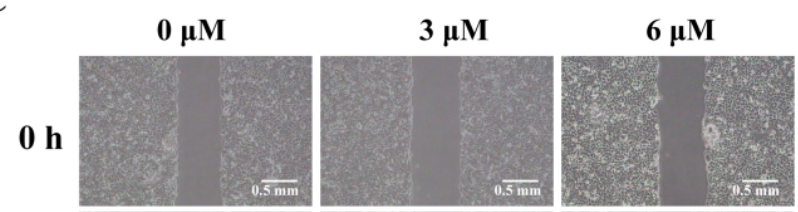

$48 \mathrm{~h}$
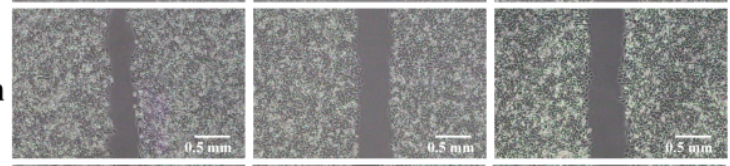

$96 \mathrm{~h}$
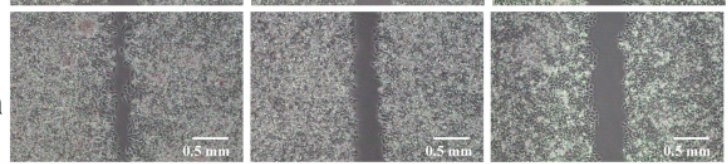

Figure 6. (A) Flow cytometry dot plot of apoptosis in MCF-7 cells induced by $3 \mathrm{c}$ at 1.5, 3, and $6 \mu \mathrm{M}$, respectively. (B) The colony formation of MCF-7 cells after being treated with $3 \mathrm{c}(1.5,3$, and $6 \mu \mathrm{M})$ for 9 days. (C) The metastasis of MCF-7 cells after being treated with $3 \mathrm{c}(3$ and $6 \mu \mathrm{M})$ for the indicated times.

Since 3c could downregulate VEGF gene transcription and expression in cancer cells, the effects of $3 c$ on the proliferation and migration of cancer cells were determined. The methyl thiazolyl tetrazolium (MTT) colorimetric assay indicated that 3c exhibited dosedependent anti-proliferation activities in MCF-7 cells with its $\mathrm{IC}_{50}$ values (the concentration for $50 \%$ inhibition) determined to be $6.5 \mu \mathrm{M}$, as shown in Supplementary Figure S11. The colony formation assay further demonstrated that the ability of MCF-7 cells to form colonies was significantly decreased in a dose-dependent manner upon treatment with increasing concentration of 3c (Figure 6B). In addition, the scrape assay indicated that MCF-7 cell metastasis was slowed down in a dose-dependent manner after being treated with $3 \mathrm{c}$ for $48 \mathrm{~h}$ and $96 \mathrm{~h}$ period (Figure $6 \mathrm{C}$ ).

These results indicated that $3 c$ could inhibit the proliferation and migration of cancer cells and induce cancer cells apoptosis possibly through downregulating VEGF gene transcription and translation.

\subsection{Molecular Modeling}

Molecular docking studies were performed to understand possible interactions of $3 c$ with VEGF promoter i-motif structure using the MOE program. Because neither the NMR nor the X-ray crystallographic structure of VEGF promoter i-motif has been reported yet, the telomeric i-motif structure (PDB ID:1ELN) [36] was used as a model structure for analyzing possible binding interaction of $3 \mathbf{c}$ with i-motif. As shown in Figure 7, the docking 
results revealed that the pentacyclic triterpenoid backbone of $3 c$ possibly lay on the i-motif groove space. The polyamine side chain of $3 \mathbf{c}$ might be positively charged in physiological conditions, and form electrostatic interactions toward the negatively charged phosphate diester backbone of DNA. The terminal amino side chain and the hydroxyl group of $3 \mathrm{c}$ could form two important H-bonds with phosphate backbone with the distances of 2.3 and $3.1 \AA$, which facilitated $3 \mathrm{c}$ twining around the i-motif structure. This could help to rationalize the significant thermal stability effect of $3 \mathrm{c}$ on Py24. Furthermore, in order to compare the binding mode of $3 \mathrm{c}$ with i-motif and G-quadruplex, the molecular docking of 3c with VEGF promoter G-quadruplex (PDB ID: 2M27) [37] was also performed. The results showed that pentacyclic triterpenoid backbone of $3 \mathrm{c}$ was unable to form the $\pi-\pi$ stacking interaction with the planar of G-quadruplex (Figure S12). With the exception of an H-bond forming between the polyamine side chain and dT22 site of phosphate diester backbone, 3c couldn't form effective interaction with G-quadruplex. These results explained the reason of the selective interaction of $3 c$ with i-motif versus G-quadruplex.

A

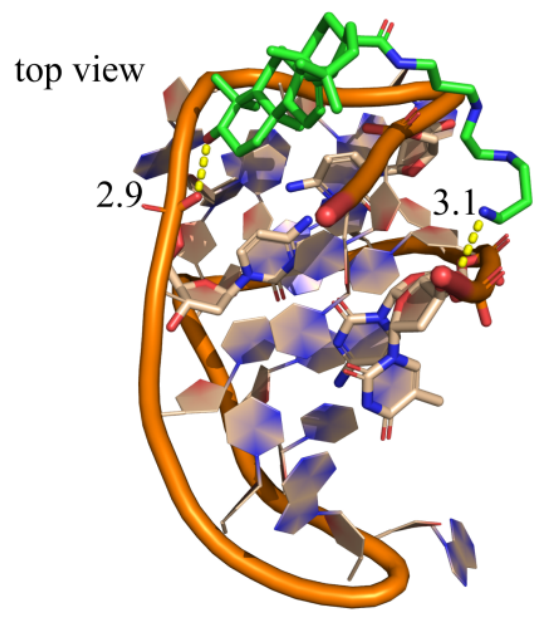

B

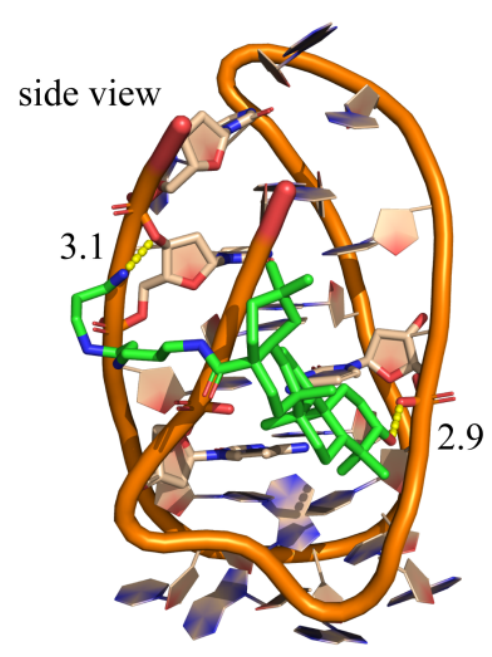

Figure 7. Hypothetical binding mode of $3 \mathrm{c}$ to i-motif secondary structures. Top views (A) and side-views (B) for the interactions of $3 \mathrm{c}$ with telomeric i-motif DNA (PDB ID: 1ELN) as well as the electrostatic interactions of the ligands with the phosphate backbone (shown in yellow dashed lines).

\section{Conclusions}

In summary, a series of oleanolic acid derivatives as VEGF promoter i-motif ligands were synthesized. The SPR experiment, TO displacement experiment and CD melting experiment were carried out to study their binding affinity and stabilizing ability to VEGF i-motif promoter. Among them, $3 \mathbf{c}$ was identified as a promising ligand, which could selectively bind to and stabilize VEGF promoter i-motif structure, without significant interaction to VEGF G-quadruplex, duplex DNA and other oncogene promoter i-motifs, including BCL2, $c-k i t, K R A S$, and PDGFR- $\beta$ i-motifs. Cell-based assays indicated that $3 c$ could effectively downregulate VEGF gene transcription and translation, and inhibit tumor cells proliferation and migration, and promote cancer cells apoptosis. Therefore, $3 \mathrm{c}$ could be used as a tool compound for the investigation on the role of VEGF promoter i-motif in regulating oncogene transcription, and as a promising lead compound for further development for anticancer therapy. This work proved that the natural oleanolic acid scaffold represents a chemotype for selective ligands of $V E G F$ i-motif and offered a new anticancer strategy with VEGF promoter i-motif as a new target.

\section{Materials and Methods}

\subsection{General Materials}

All chemicals and starting materials were purchased from commercial sources, which were analytical grade without further purification unless otherwise specified. NMR spectra 
were recorded on a Bruker BioSpin $\mathrm{GmbH} 400 \mathrm{MHz}$ or $500 \mathrm{MHz}$ spectrometer using TMS (tetramethylsilane) as the internal standard. High-resolution mass spectra (HRMS) were recorded on Shimadzu LCMS-IT-TOF of MAT95XP mass spectrometer (Thermo Fisher Scientific, Waltham, MA, USA). All oligomers/primers used in this study were purchased from Invitrogen or Sangon, as shown in Table S1 in the Supporting Information. CD experiments were performed on a Chirascan circular dichroism spectrophotometer (Applied Photophysics, Leatherhead, UK). Fluorescence experiments were performed on Fluoromax4 luminescence spectrophotometer (Horiba Jobin-Yvon, Paris, France). ITC experiments were performed using a MicroCal VP-ITC instrument (GE Healthcare, Northampton, MA, USA). For obtaining i-motif structures, $\mathrm{C}$-rich oligonucleotides were annealed in $1 \times \mathrm{BPES}$ buffer ( $30 \mathrm{mM} \mathrm{KH} \mathrm{PO}_{4}, 30 \mathrm{mM} \mathrm{K}_{2} \mathrm{HPO}_{4}, 1 \mathrm{mM}$ EDTA, $100 \mathrm{mM} \mathrm{KCl}$ ) with different $\mathrm{pH}$ at $95^{\circ} \mathrm{C}$ for $5 \mathrm{~min}$, and then cooled to room temperature. For obtaining G-quadruplex, oligonucleotides were annealed in $20 \mathrm{mM}$ Tris- $\mathrm{HCl}$ buffer containing $100 \mathrm{mM} \mathrm{KCl}$ (pH 7.4) by heating at $95{ }^{\circ} \mathrm{C}$ for $5 \mathrm{~min}$ followed with gradual cooling to room temperature.

\subsection{Synthesis}

All synthetic procedures, yields, and physical and spectroscopic data for the compounds are included in the Supplementary Materials.

\subsection{Surface Plasmon Resonance (SPR) Assay}

SPR assay was performed on a ProteOn XPR36 Protein Interaction Array system (BioRad Laboratories, Hercules, CA, USA) using a NeutrAvidin-coated GLH sensor chip. For immobilization, all DNA samples were biotinylated and attached to a reptavidin-coated sensor chip. $5^{\prime}$-Biotin labeled Py24 were diluted to $1 \mu \mathrm{M}$ in running buffer $(20 \mathrm{mM} 2-(4-$ morpholino)ethanesulfonic acid, pH 5.5, $100 \mathrm{mM} \mathrm{KCl}$ and 0.05\% Tween-20), and 5'-biotin Pu24 and 5'-biotin duplex DNA were diluted to $1 \mu \mathrm{M}$ in running buffer (Tris- $\mathrm{HCl} 20 \mathrm{mM}$, pH 7.4, $100 \mathrm{mM} \mathrm{KCl})$. The DNA samples were then captured (1000 RU) in flow cells, and a blank cell was set as a control. All ligands were prepared with the running buffer through serial dilutions from stock solution (10 $\mathrm{mM}$ in DMSO). Ligands of different concentrations were injected at a flow rate of $30 \mu \mathrm{L} / \mathrm{min}$ for $120 \mathrm{~s}$ of association phase, followed with $120 \mathrm{~s}$ of dissociation phase at $25^{\circ} \mathrm{C}$. The GLH sensor chip was regenerated with short injection of $50 \mathrm{mM} \mathrm{NaOH}$ between consecutive measurements. The final graphs were obtained by subtracting blank sensorgrams from the i-motif, G-quadruplex, or duplex sensorgrams. Data was analyzed by using ProteOn manager software.

\subsection{Microscale Thermophoresis (MST) Assay}

The thermophoresis movements of the fluorescently labeled nucleic acids and $3 \mathrm{c}$ complexes were analyzed by monitoring the fluorescence distributions inside the capillary by using the NT.115 MST instrument (NanoTemper, München, Germany). The concentration of DNA was held constant at $1 \mu \mathrm{M}$. The compound was diluted at 1:1 from 100 $\mu \mathrm{M}$ for 16 times. The samples were loaded into standard-treated MST-grade glass capillaries. The intensities of the light-emitting diode (LED) and laser were set as $40 \%$ and $40 \%$, respectively. Data was analyzed by using NT Analysis 1.4.23 software (NanoTemper, München, Germany).

\subsection{TO Displacement Assay}

I-motif or G-quadruplex oligonucleotides solution $(1 \mu \mathrm{M}, 100 \mu \mathrm{L})$ was added to the cuvette, followed with addition of thiazole orange $(2 \mu \mathrm{M})$. The spectrum of the oligonucleotide with titration of $3 c$ was recorded based on fluorescence emission $\left(\lambda_{\mathrm{ex}}=480 \mathrm{~nm}\right)$.

\subsection{ESI-MS Assay}

The oligomer Py24 $(5 \mu \mathrm{M})$ was annealed in the presence or absence of $3 \mathrm{c}$ in $1 \times$ BPES buffer (10 mM KH $\mathrm{PO}_{4}, 10 \mathrm{mM} \mathrm{K} \mathrm{HPO}_{4}, 1 \mathrm{mM}$ EDTA, $100 \mathrm{mM} \mathrm{KCl}$, pH 5.0 or pH 7.5) at 
$95^{\circ} \mathrm{C}$ for $5 \mathrm{~min}$. The solution was gradually cooled to room temperature, and detected by using an electrospray ionization (ESI) mass spectrometer.

\subsection{Isothermal Titration Calorimetry Assay}

The oligomer Py 24 was diluted from stock to the indicated concentration $(0.80 \mathrm{mM})$ in $1 \times$ BPES buffer at $\mathrm{pH} 5.0$ and then annealed by heating at $95^{\circ} \mathrm{C}$ for $5 \mathrm{~min}$. The solution was gradually cooled to room temperature to generate i-motif structure. The oligomer Py24 was titrated into $3 \mathrm{c}(0.08 \mathrm{mM})$ at $30^{\circ} \mathrm{C}$ in $10 \mu \mathrm{L}$ injections with a spacing of $300 \mathrm{~s}$ between injections. The integrated heat data were corrected for the heat of dilution and blank effects. The binding isotherms were fitted with the one-site binding model incorporated into the MicroCal Origin VPITC software.

\subsection{Circular Dichroism Spectroscopy}

A quartz cuvette with $4 \mathrm{~mm}$ path length was used for the spectra recorded over a wavelength range of $230-350 \mathrm{~nm}$ at $1 \mathrm{~nm}$ bandwidth. The oligomer Py24 was diluted from stock to the required concentration $(1 \mu \mathrm{M})$ in $1 \times$ BPES buffer at pH 5.0 or 6.0 and then annealed by heating at $95^{\circ} \mathrm{C}$ for $5 \mathrm{~min}$. The solution was gradually cooled to room temperature, and incubated with $3 \mathrm{c}$ at $37^{\circ} \mathrm{C}$ for $1 \mathrm{~h}$. Spectra were recorded three times, averaged, smoothed, and baseline corrected to remove signal contribution from buffer. The data was analyzed by using Origin 9.0 (OriginLab, Northampton, MA, USA).

For CD melting assays, thermal melting was monitored at $230-350 \mathrm{~nm}$ with a $1 \mathrm{~nm}$ bandwidth. CD melting assays were performed at a fixed DNA concentration $(2 \mu \mathrm{M})$ with or without $3 \mathrm{c}$ in relevant buffer. The data were recorded at intervals of $5^{\circ} \mathrm{C}$ over a range of $20-95{ }^{\circ} \mathrm{C}$ with a heating rate of $1{ }^{\circ} \mathrm{C} / \mathrm{min}$.

\subsection{Fluorescence Resonance Energy Transfer (FRET) Assay}

Oligomer Py24 with a $5^{\prime}$-end FAM-fluorophore and a $3^{\prime}$-end TAMRA are provided in Table S1. The fluorescence of a fixed concentration $(0.1 \mu \mathrm{M})$ of oligonucleotide was tested $\left(\lambda_{\mathrm{ex}}=480 \mathrm{~nm}\right)$ with the titration of $3 \mathrm{c}$.

\subsection{NMR Titration Experiment}

The DNA oligonucleotide was purchased from Sangon (China). The final NMR samples were prepared in $1 \times$ BPES buffer containing $10 \% \mathrm{D}_{2} \mathrm{O}$ at pH 5.0 or 6.0. The concentration of DNA sample was set at $1.0 \mathrm{mM}$. The stock solution of $3 \mathrm{c}$ was dissolved in DMSO- $d_{6} .{ }^{1} \mathrm{H}$ NMR titration experiments were performed on a Bruker DRX-600 MHz spectrometer at $25^{\circ} \mathrm{C}$, and the water signal was suppressed.

\subsection{Cell Culture}

Human breast adenocarcinoma cell line MCF-7 was purchased from China Center for Type Culture Collection in Wuhan. The cell line was maintained in DMEM (Dulbecco's Modified Eagle's medium), supplemented with $10 \%$ fetal calf serum, $100 \mathrm{U} / \mathrm{mL}$ Penicillium, and $100 \mathrm{mg} / \mathrm{mL}$ streptomycin at $37{ }^{\circ} \mathrm{C}$ in a humidified atmosphere with $5 \% \mathrm{CO}_{2}$.

\subsection{MTT Assay}

Human breast adenocarcinoma cells MCF-7 were seeded on 96-well plates (5000 cells/well) and treated with $3 \mathrm{c}$ at various concentrations. After $48 \mathrm{~h}$ treatment at $37^{\circ} \mathrm{C}$ in a humidified atmosphere of $5 \% \mathrm{CO}_{2}, 20 \mu \mathrm{L}$ of $2.5 \mathrm{mg} / \mathrm{mL}$ 3-(4,5-dimethyl-2-thiazolyl)-2,5-diphenyl$2 \mathrm{H}$-tetrazolium bromide (MTT) solution was added to each well and further incubated for $4 \mathrm{~h}$. The cells in each well were then treated with DMSO (200 $\mu \mathrm{L}$ for each well), and the optical density (OD) was recorded at $570 \mathrm{~nm}$. The cytotoxicity was evaluated based on the percentage of cell survival in a dose-dependent manner regard to the blank. The final IC 50 values (the concentration for $50 \%$ inhibition) were calculated by using the Prism 8 Computer Software (GraphPad, San Diego, CA, USA). All of the experiments were repeated three times. 


\subsection{Colony Formation Assay}

MCF-7 cells were subsequently seeded in 6-well culture plates (1000/well) for $24 \mathrm{~h}$ pre-culture at $37{ }^{\circ} \mathrm{C}$ in a humidified atmosphere with $5 \% \mathrm{CO}_{2}$, and then treated with $3 \mathrm{c}$ at different concentrations for 9 days. The cells were washed with $1 \times$ PBS and fixed with ice cold methanol for $10 \mathrm{~min}$, followed by the addition of $0.5 \%$ crystal violet solution for $30 \mathrm{~min}$ to observe the colony formation.

\subsection{Cell Scrape Assay}

MCF-7 cells were subsequently seeded in 6-well culture plates (300,000/well) at $37^{\circ} \mathrm{C}$ in a humidified atmosphere with $5 \% \mathrm{CO}_{2}$. After being pre-cultured for $48 \mathrm{~h}$, a cross-shaped scrape was made through the monolayer Siha cells using a plastic pipet tip, and then the cells were treated with $3 \mathbf{c}$ at different concentrations. The wounded areas were observed and photographed using microscopy after being incubated for the indicated times.

\subsection{Flow Cytometric Analysis}

MCF-7 cells were seeded in 6-well plate $\left(2 \times 10^{5} /\right.$ well $)$ and incubated for $24 \mathrm{~h}$ at $37^{\circ} \mathrm{C}$ in a humidified atmosphere with $5 \% \mathrm{CO}_{2}$. After being incubated in the presence and absence of $3 \mathrm{c}$ for $48 \mathrm{~h}$, the Siha cells were then washed in PBS, and centrifuged and re-suspended in Annexin V-FITC solution for $15 \mathrm{~min}$ at room temperature in dark. After centrifuged for $5 \mathrm{~min}$, the cells were then re-suspended in Annexin V-FITC solution and mixed with PI staining solution for $10 \mathrm{~min}$ at $2-5{ }^{\circ} \mathrm{C}$ in dark. Then, the cells were analyzed by using flow cytometry with an Epics Elite flow cytometer (Beckman Coulter, Brea, CA, USA).

\subsection{Dual-Luciferase Reporter Assay}

A total of $100 \mathrm{ng}$ of constructed pGL4.10 luciferase plasmid (Promega, Madison, WI, USA) containing VEGF corresponding upstream i-motif elements and $100 \mathrm{ng}$ plt-tk Renilla plasmid were transfected into MCF-7 cells by using Lipofectamine 3000 (Invitrogen, Carlsbad, CA, USA). After $6 \mathrm{~h}$, the solution of $3 \mathrm{c}$ was added to the cells. The cells were incubated at $37^{\circ} \mathrm{C}$ with $\mathrm{CO}_{2}$ for $24 \mathrm{~h}$, and the transfected cells were first washed with ice-cold PBS to reduce the background signals from the medium. Luciferase assays were subsequently performed according to the manufacturer's instructions using the dualluciferase assay system (Promega, Madison, WI, USA). After a $3 \mathrm{~s}$ delay, secreted luciferase signals were collected for $10 \mathrm{~s}$ using a microplate reader (Molecular Devices, Sunnyvale, CA, USA). The quantification was performed using a multimode reader (Molecular Devices, Sunnyvale, CA, USA). The secreted Renilla luciferase activity was normalized to the firefly luciferase activity.

\subsection{RNA Extraction and Real Time Polymerase Chain Reaction (RT-PCR)}

MCF-7 cells were seeded in 6-well plate $\left(2 \times 10^{5}\right.$ cells /well), and incubated for $24 \mathrm{~h}$ at $37^{\circ} \mathrm{C}$ in a humidified atmosphere with $5 \% \mathrm{CO}_{2}$. After the cells were incubated in the presence or absence of $3 \mathrm{c}$ for $48 \mathrm{~h}$, cells were harvested, and the RNA was extracted by using HiPure Total RNA Mini Kit (Magen, Guangzhou, China). Quantitative real-time polymerase chain reaction (PCR) was carried out using $2 \times$ RealStar SYBR Mixture (Genstar, Guangzhou, China). The results were analyzed on a LightCycler480 II real-time PCR system (Roche, Basel, Switzerland). The oncogene mRNA levels were normalized to $\beta$ actin mRNA level of each sample. Results of real-time PCR were analyzed by using the $2^{-\Delta \mathrm{Ct}}$ method.

\subsection{Western Blot Assay}

MCF-7 cells were seeded in 6-well plate $\left(2 \times 10^{5}\right.$ cells/well $)$ and incubated for $24 \mathrm{~h}$ at $37^{\circ} \mathrm{C}$ in a humidified atmosphere with $5 \% \mathrm{CO}_{2}$. After being incubated in the presence and absence of $3 \mathrm{c}$ for $48 \mathrm{~h}$, cells were harvested from each well of culture plates and lysed in $200 \mu \mathrm{L}$ of protein extraction buffer consisting of $1 \mathrm{mM}$ PMSF for $30 \mathrm{~min}$. The 
suspension was centrifuged at $10,000 \mathrm{rpm}$ at $4{ }^{\circ} \mathrm{C}$ for $15 \mathrm{~min}$, and the protein content of supernatant was measured by using bicinchoninic acid (BCA) assay. The same amount of protein for each sample was loaded onto $8 \%$ polyacrylamide gel, and then transferred to a microporous polyvinylidene difluoride (PVDF) membrane. Western blotting was performed by using anti-VEGF and anti- $\beta$-GAPDH (cell signaling technology) antibodies, as well as horseradish peroxidase-conjugated anti-rabbit secondary antibody. Protein bands were visualized by using chemiluminescence substrate.

\subsection{Molecular Docking}

The telomeric i-motif DNA and VEGF G-quadruplex structures were downloaded from Protein Data Bank (1ELN, 2M27). After optimization of the ligand and assigning partial atomic charges, docking calculations were performed with the MOE program. The ligand to be modeled was constructed and optimized by using ChemDraw and saved in SDF file format, and was minimized with the conjugate gradient method using the MMFF94x force field with MMFF94 charges. The process of site finder was performed using MOE software (Chemical Computing Group, Montreal, Canada) to determine the binding sites. Docking runs were carried out and the ligand conformation was chosen based on the docked energy. The final graphs were created by using PyMOL software (Schrödinger, New York, NY, USA).

Supplementary Materials: Supplementary data to this article can be found online at https://www. mdpi.com/1422-0067/22/4/1711/s1.

Author Contributions: Chemical synthesis, biological experiments, acquisition, analysis and interpretation of data, preparation of manuscript, docking studies (H.Z.); biological experiments, acquisition, analysis and interpretation of data, preparation of manuscript (S.K.); biological experiments, acquisition of data (Y.Z.); chemical synthesis (K.L.); chemical synthesis (Q.Y.); conception and design, analysis, and interpretation of data, revision of the manuscript (D.L.); conception and design, study supervision, analysis and interpretation of data, revision of the manuscript (L.-K.A.). All authors have read and agreed to the published version of the manuscript.

Funding: This research was funded by the National Natural Science Foundation of China (21977123), Guangdong Basic and Applied Basic Research Foundation (2019A1515011317, 2019A1515011074), Guangdong Provincial Key Laboratory of Construction Foundation (2017B030314030), and the Fundamental Research Funds for the Central Universities (19YKPY127).

Institutional Review Board Statement: Not applicable.

Informed Consent Statement: Not applicable.

Data Availability Statement: The data presented in this study are available in both article and Supplementary Materials.

Conflicts of Interest: The authors confirm that this article content has no conflict of interest.

\section{References}

1. Apte, R.S.; Chen, D.S.; Ferrara, N. VEGF in Signaling and Disease: Beyond Discovery and Development. Cell 2019, 176, 1248-1264. [CrossRef]

2. Mochizuki, M.; Güç, E.; Park, A.J.; Julier, Z.; Briquez, P.S.; Kuhn, G.A.; Müller, R.; Swartz, M.A.; Hubbell, J.A.; Martino, M.M. Growth factors with enhanced syndecan binding generate tonic signalling and promote tissue healing. Nat. Biomed. Eng. 2020, 4, 463-475. [CrossRef]

3. Yu, P.; Wilhelm, K.; Dubrac, A.; Tung, J.K.; Alves, T.C.; Fang, J.S.; Xie, Y.; Zhu, J.; Chen, Z.; De Smet, F.; et al. FGF-dependent metabolic control of vascular development. Nature 2017, 545, 224-228. [CrossRef]

4. Fukumura, D.; Kloepper, J.; Amoozgar, Z.; Duda, D.G.; Jain, R.K. Enhancing cancer immunotherapy using antiangiogenics: Opportunities and challenges. Nat. Rev. Clin. Oncol. 2018, 15, 325-340. [CrossRef]

5. Tamura, R.; Fujioka, M.; Morimoto, Y.; Ohara, K.; Kosugi, K.; Oishi, Y.; Sato, M.; Ueda, R.; Fujiwara, H.; Noji, S.; et al. A VEGF receptor vaccine demonstrates preliminary efficacy in neurofibromatosis type 2. Nat. Commun. 2019, 10, 5758. [CrossRef]

6. McDermott, D.F.; Huseni, M.A.; Atkins, M.B.; Motzer, R.J.; Rini, B.I.; Escudier, B.; Fong, L.; Joseph, R.W.; Pal, S.K.; Reeves, J.A.; et al. Clinical activity and molecular correlates of response to atezolizumab alone or in combination with bevacizumab versus sunitinib in renal cell carcinoma. Nat. Med. 2018, 24, 1941. [CrossRef] [PubMed] 
7. Zeraati, M.; Langley, D.B.; Schofield, P.; Moye, A.L.; Rouet, R.; Hughes, W.E.; Bryan, T.M.; Dinger, M.E.; Christ, D. I-motif DNA structures are formed in the nuclei of human cells. Nat. Chem. 2018, 10, 631-637. [CrossRef] [PubMed]

8. Abou Assi, H.; Garavis, M.; Gonzalez, C.; Damha, M.J. I-Motif DNA: Structural features and significance to cell biology. Nucleic Acids Res. 2018, 46, 8038-8056. [CrossRef]

9. Debnath, M.; Fatma, K.; Dash, J. Chemical Regulation of DNA i-Motifs for Nanobiotechnology and Therapeutics. Angew. Chem. Int. Ed. Engl. 2019, 58, 2942-2957. [CrossRef] [PubMed]

10. Day, H.A.; Pavlou, P.; Waller, Z.A.E. i-Motif DNA: Structure, stability and targeting with ligands. Biorg. Med. Chem. 2014, 22, 4407-4418. [CrossRef]

11. Brown, R.V.; Wang, T.; Chappeta, V.R.; Wu, G.; Onel, B.; Chawla, R.; Quijada, H.; Camp, S.M.; Chiang, E.T.; Lassiter, Q.R.; et al. The Consequences of Overlapping G-Quadruplexes and i-Motifs in the Platelet-Derived Growth Factor Receptor $\beta$ Core Promoter Nuclease Hypersensitive Element Can Explain the Unexpected Effects of Mutations and Provide Opportunities for Selective Targeting of Both Structures by Small Molecules To Downregulate Gene Expression. J. Am. Chem. Soc. 2017, 139, 7456-7475.

12. Kendrick, S.; Kang, H.-J.; Alam, M.P.; Madathil, M.M.; Agrawal, P.; Gokhale, V.; Yang, D.; Hecht, S.M.; Hurley, L.H. Correction to “The Dynamic Character of the BCL2 Promoter i-Motif Provides a Mechanism for Modulation of Gene Expression by Compounds That Bind Selectively to the Alternative DNA Hairpin Structure". J. Am. Chem. Soc. 2016, 138, 11408. [CrossRef] [PubMed]

13. Kaiser, C.E.; Van Ert, N.A.; Agrawal, P.; Chawla, R.; Yang, D.; Hurley, L.H. Insight into the Complexity of the i-Motif and G-Quadruplex DNA Structures Formed in the KRAS Promoter and Subsequent Drug-Induced Gene Repression. J. Am. Chem. Soc. 2017, 139, 8522-8536. [CrossRef] [PubMed]

14. Shu, B.; Cao, J.; Kuang, G.; Qiu, J.; Zhang, M.; Zhang, Y.; Wang, M.; Li, X.; Kang, S.; Ou, T.-M.; et al. Syntheses and evaluation of new acridone derivatives for selective binding of oncogene c-myc promoter i-motifs in gene transcriptional regulation. Chem. Commun. 2018, 54, 2036-2039. [CrossRef]

15. Debnath, M.; Ghosh, S.; Chauhan, A.; Paul, R.; Bhattacharyya, K.; Dash, J. Preferential targeting of i-motifs and G-quadruplexes by small molecules. Chem. Sci. 2017, 8, 7448-7456. [CrossRef] [PubMed]

16. Kuang, G.; Zhang, M.; Kang, S.; Hu, D.; Li, X.; Wei, Z.; Gong, X.; An, L.-K.; Huang, Z.-S.; Shu, B.; et al. Syntheses and Evaluation of New Bisacridine Derivatives for Dual Binding of G-Quadruplex and i-Motif in Regulating Oncogene c-myc Expression. J. Med. Chem. 2020, 63, 9136-9153. [CrossRef]

17. Guo, K.; Gokhale, V.; Hurley, L.H.; Sun, D. Intramolecularly folded G-quadruplex and i-motif structures in the proximal promoter of the vascular endothelial growth factor gene. Nucleic Acids Res. 2008, 36, 4598-4608. [CrossRef] [PubMed]

18. Wu, Y.; Zan, L.P.; Wang, X.D.; Lu, Y.J.; Ou, T.M.; Lin, J.; Huang, Z.S.; Gu, L.Q. Stabilization of VEGF G-quadruplex and inhibition of angiogenesis by quindoline derivatives. Biochim. Biophys. Acta 2014, 1840, 2970-2977. [CrossRef]

19. Jana, J.; Mondal, S.; Bhattacharjee, P.; Sengupta, P.; Roychowdhury, T.; Saha, P.; Kundu, P.; Chatterjee, S. Chelerythrine down regulates expression of VEGFA, BCL2 and KRAS by arresting G-Quadruplex structures at their promoter regions. Sci. Rep. 2017, 7, 40706. [CrossRef] [PubMed]

20. Asamitsu, S.; Obata, S.; Yu, Z.; Bando, T.; Sugiyama, H. Recent Progress of Targeted G-Quadruplex-Preferred Ligands Toward Cancer Therapy. Molecules 2019, 24, 429. [CrossRef] [PubMed]

21. Neidle, S. Quadruplex Nucleic Acids as Novel Therapeutic Targets. J. Med. Chem. 2016, 59, 5987-6011. [CrossRef]

22. Che, T.; Chen, S.B.; Tu, J.L.; Wang, B.; Wang, Y.Q.; Zhang, Y.; Wang, J.; Wang, Z.Q.; Zhang, Z.P.; Ou, T.M.; et al. Discovery of Novel Schizocommunin Derivatives as Telomeric G-Quadruplex Ligands That Trigger Telomere Dysfunction and the Deoxyribonucleic Acid (DNA) Damage Response. J. Med. Chem. 2018, 61, 3436-3453. [CrossRef] [PubMed]

23. Zeng, D.-Y.; Kuang, G.-T.; Wang, S.-K.; Peng, W.; Lin, S.-L.; Zhang, Q.; Su, X.-X.; Hu, M.-H.; Wang, H.; Tan, J.-H.; et al. Discovery of Novel 11-Triazole Substituted Benzofuro[3,2-b]quinolone Derivatives as c-myc G-Quadruplex Specific Stabilizers via Click Chemistry. J. Med. Chem. 2017, 60, 5407-5423. [CrossRef] [PubMed]

24. Peng, W.; Sun, Z.-Y.; Zhang, Q.; Cheng, S.-Q.; Wang, S.-K.; Wang, X.-N.; Kuang, G.-T.; Su, X.-X.; Tan, J.-H.; Huang, Z.-S.; et al. Design, Synthesis, and Evaluation of Novel p-(Methylthio)styryl Substituted Quindoline Derivatives as Neuroblastoma RAS (NRAS) Repressors via Specific Stabilizing the RNA G-Quadruplex. J. Med. Chem. 2018, 61, 6629-6646. [CrossRef] [PubMed]

25. Sparapani, S.; Haider, S.M.; Doria, F.; Gunaratnam, M.; Neidle, S. Rational Design of Acridine-Based Ligands with Selectivity for Human Telomeric Quadruplexes. J. Am. Chem. Soc. 2010, 132, 12263-12272. [CrossRef]

26. Rodrigues, T.; Reker, D.; Schneider, P.; Schneider, G. Counting on natural products for drug design. Nat. Chem. 2016, 8, 531-541. [CrossRef]

27. Meng, L.K.; Su, Y.Q.; Yang, F.; Xiao, S.L.; Yin, Z.L.; Liu, J.X.; Zhong, J.D.; Zhou, D.M.; Yu, F. Design, synthesis and biological evaluation of amino acids-oleanolic acid conjugates as influenza virus inhibitors. Biorg. Med. Chem. 2019, 27, 115147. [CrossRef]

28. Wang, H.; Xu, R.; Shi, Y.; Si, L.; Jiao, P.; Fan, Z.; Han, X.; Wu, X.; Zhou, X.; Yu, F.; et al. Design, synthesis and biological evaluation of novel L-ascorbic acid-conjugated pentacyclic triterpene derivatives as potential influenza virus entry inhibitors. Eur. J. Med. Chem. 2016, 110, 376-388. [CrossRef]

29. Su, Y.Q.; Meng, L.K.; Sun, J.Q.; Li, W.J.; Shao, L.; Chen, K.X.; Zhou, D.M.; Yang, F.; Yu, F. Design, synthesis of oleanolic acidsaccharide conjugates using click chemistry methodology and study of their anti-influenza activity. Eur. J. Med. Chem. 2019, 182, 111-622. [CrossRef]

30. Del Prete, D.; Taglialatela-Scafati, O.; Minassi, A.; Sirignano, C.; Cruz, C.; Bellido, M.L.; Munoz, E.; Appendino, G. Electrophilic Triterpenoid Enones: A Comparative Thiol-Trapping and Bioactivity Study. J. Nat. Prod. 2017, 80, 2276-2283. [CrossRef] 
31. Farina, C.; Pinza, M. Synthesis of new 12-oxo derivatives of oleanolic acid with $13 \alpha$ configuration. Gazz. Chim. Ital. 1987, $117,561-562$.

32. Martinez, A.; Perojil, A.; Rivas, F.; Parra, A.; Garcia-Granados, A.; Fernandez-Vivas, A. Biotransformation of oleanolic and maslinic methyl esters by Rhizomucor miehei CECT 2749. Phytochemistry 2015, 117, 500-508. [CrossRef]

33. Li, W.; Yang, F.; Meng, L.; Sun, J.; Su, Y.; Shao, L.; Zhou, D.; Yu, F. Synthesis, structure activity relationship and anti-influenza A virus evaluation of oleanolic acid-linear amino derivatives. Chem. Pharm. Bull. 2019, 67, 1201-1207. [CrossRef] [PubMed]

34. Molnar, M.M.; Liddell, S.C.; Wadkins, R.M. Effects of Polyamine Binding on the Stability of DNA i-Motif Structures. Acs Omega 2019, 4, 8967-8973. [CrossRef]

35. Kumar, N.; Basundra, R.; Maiti, S. Elevated polyamines induce c-MYC overexpression by perturbing quadruplex-WC duplex equilibrium. Nucleic Acids Res. 2009, 37, 3321-3331. [CrossRef]

36. Phan, A.T.; Gueron, M.; Leroy, J.L. The solution structure and internal motions of a fragment of the cytidine-rich strand of the human telomere. J. Mol. Biol. 2000, 299, 123-144. [CrossRef]

37. Agrawal, P.; Hatzakis, E.; Guo, K.; Carver, M.; Yang, D. Solution structure of the major G-quadruplex formed in the human VEGF promoter in K+: Insights into loop interactions of the parallel G-quadruplexes. Nucleic Acids Res. 2013, 41, 10584-10592. [CrossRef] [PubMed] 